\title{
INTERNATIONAL LEGAL COOPERATION AND THE PRINCIPLE OF PUBLIC POLICY: LESSONS FROM INTELLECTUAL PROPERTY LAW
}

\author{
Nadia Naim ${ }^{1}$ \\ Birmingham City University, United Kingdom
}

\begin{abstract}
This research paper will examine the different approaches to corporate legal theory in the international legal co-operation of International Intellectual Property (IP). The focus will be on legal cooperation as a means to promoting harmonisation in line with international standard setting from the World Intellectual Property Office (WIPO) and the World Trade Organisation (WTO). Harmonisation can be seen through the minimum standards set through WIPO for all WTO members known as Trade Related Intellectual Property Rights (TRIPS). The landmark cases of Philip Morris v. The Commonwealth of Australia and Eli Lilly v Canada will be discussed as a case study to highlight the lack of harmonisation between Intellectual Property, corporate sovereignty and Investor to State Dispute Settlements (ISDS). This abstract presents the initial hypotheses and some primary conclusions from the research.
\end{abstract}

Keywords: International Legal Cooperation, public policy, intellectual property law.

Contents: 1 Introduction. 2 Public policy implications for harmonisation of international IP. 3 The harmonisation of public policy and intellectual property - Case studies.

\section{INTRODUCTION}

Intellectual Property Rights are not the only form of internationally recognised form of rights subject to treaties and multilateral agreements: public policy issues are also dealt with in this way, but the two subjects have historically been dealt with in different ways. This paper intends to get you to consider the relationship between these two subjects, and whether either is more significant or more important than the other. The issue at hand is that IP rights are territorial in nature and monopolise the market whereas public policy considerations come into play when there are competing interests between the private investor and Governments. The ramifications of the current divergence from taking into account the dichotomy between IP right and public policy, can be exemplified through the case study analysis of Eli Lilly and Philip Morris. Both cases deal with IP rights, international trade agreements and corporations taking Governments to Court over an alleged breach of IP rights within the trade agreements.

\footnotetext{
${ }^{1}$ Senior Lecturer in Law. Nadia.Naim@bcu.ac.uk
} 


\section{Public Policy Implications fOR HARMonisation OF INTERNATIONAL IP}

At the heart of all trade agreements and negotiations between different states and blocs is one fundamental principle, to increase economic ties between the trading partners. Intellectual property infringement costs the G20 countries \$125 billion annually; this includes losses in tax revenue from counterfeiting and piracy $^{2}$. In terms of the global economy, the International Chambers of Commerce (ICC) estimates the losses to the global economy from intellectual property infringements at $\$ 1$ trillion annually. ${ }^{3}$

The EC clearly appreciates the importance of IP rights, since they are specifically mentioned as a type of derogation from Articles 34 and states the provisions of Articles 34 and 35 shall not preclude prohibitions or restrictions on imports, exports or goods in transit justified on grounds of public morality, public policy or public security.

Whilst recognising these rights, the EU has sought to limit their effect due to their monopolistic nature. One way the EU has sought to do this is by encouraging businesses to seek protection of IP rights on a Community wide basis, through, inter alia, Designs Directive (98/71/EC), Regulation on Community Design 2001 (6/2002/EC), and EU Directive 89/104/EC regarding trade marks. However, whilst the existence of these instruments makes it easier to protect some IP rights throughout the EU as a whole, the EU cannot prevent businesses from exploiting different IP rights in different member states. Therefore, it has fallen to the ECJ to try to balance the competing interests that have arisen as a result of this conflict, i.e. free movement of goods vs. protection of IP rights.

At a national level, all IP legislation has public policy as an exception however how effective that is remains to be seen. As an example, The Patents Act 1977 at s1 (3) states that it is not possible to patent inventions whose commercial exploitation would be immoral or contrary to public policy. In view of the rise of genetic engineering and biotechnology, this is an increasingly contested area. In Harvard College's Onco Mouse Application, ${ }^{4}$ the case concerned a method of producing mice that would be born with cancer so that they could be used for medical experimentation. The case raised technical issues relating to what constitutes biological processes as well as questions of the morality and desirability of genetic engineering. On initial examination, the patent examiner did not consider the morality of this development. However, on appeal the board of appeal recognised the deep moral implications of

\footnotetext{
${ }^{2}$ Business Action to Stop Counterfeiting and Piracy (BASCAP), Estimating the Global Economic and Social Impacts of Counterfeiting and Piracy, FRONTIER ECONOMICS (Feb. 2011).

${ }^{3}$ Ibid.

${ }^{4}$ Harvard College's Onco Mouse Application, T 19/90 [1990] OJ EPOR 501 (Oct. 3, 1990).
} 
manipulating the mice's genes to guarantee they would develop cancer, and instructed the examiner to "weigh up the suffering of animals and possible risks to the environment on one hand, and the invention's usefulness to mankind on the other." Applying this utilitarian balancing test, the examiner once again approved the patent.

Two years later, the European Patent Office refused an application to patent a mouse into which a gene had been introduced to cause the mouse to lose its hair, as it found the benefits (research into hair loss) did not outweigh the harm to the mice.

As a means of ensuring a balance between IP rights and free movement of goods, in the 1970s the ECJ began to develop the doctrine of "Exhaustion of Rights". The principle was initially defined thus in Terrapin $v$ Terranova ${ }^{5}$ as:

The Proprietor of an industrial or commercial property right protected by the law of a member state cannot rely on that law to prevent the importation of a product which has lawfully been marketed in another member state by the proprietor himself or with his consent. ${ }^{6}$

This is not dependent on whether the first sale/marketing is in a member state where an IP right exists; it is sufficient that the goods are put into circulation by, or with the consent of, the owner of the IP right. Therefore in Merck v Stephar, ${ }^{7}$ a patent was held in every EC state except Italy. Defendants imported Merck's product, marketed in Italy, into Holland. Held, free movement rules of EC treaty prevented Merck from using their Dutch patent to prevent sales in Holland.

\section{The harmonisation of Public policy and Intellectual Property - Case STUDIES}

In relation to intellectual property, lessons can be learnt from existing intellectual property based ISDS cases. Take for example Eli Lilly v. Canada. ${ }^{8}$ In November 2012, Eli Lilly \& Co started proceedings against the Canadian government's law on granting drug patents, claiming that the invalidation of a patent undermined the company's future profits and are asking for $\$ 500$ million in compensation Claimant has submitted the present dispute to international arbitration pursuant to Chapter Eleven of the North American Free Trade Agreement, which entered into force on 1 January 1994 ("NAFTA"), and the United Nations Commission on International Trade Law's Arbitration Rules as adopted by General Assembly

\footnotetext{
${ }^{5}$ Terrapin v. Terranova [1976] ECR 1039 (June 22, 1976).

${ }^{6}$ Ibid

${ }^{7}$ Merck v. Stephar [July 14, 1981] CMLR 463.

${ }^{8}$ Eli Lilly and Company v. Canada, Case No. UNCT/14/2.
} 
Resolution 31/98 on 15 December 1976 (“UNCITRAL Rules”). By agreement of the Parties, the International Centre for Settlement of Investment Disputes (“ICSID”) serves as the administering authority for this proceeding. In this arbitration, Claimant asserts claims arising from the invalidation of its Canadian patents protecting the drugs marketed in Canada as Strattera and Zyprexa. The Canadian courts invalidated these two patents in 2010 and 2011, respectively, on the ground that they did not meet the requirement under Canadian patent law that an invention be "useful".

Further the case of Philip Morris highlights the real threat that corporate sovereignty can impose for domestic legislation and public policy at large. Australia won the international legal battle to uphold its control measures on tobacco with Philip Morris arguing it infringed their trademarks. ${ }^{9}$ The public policy issued raised by the case is a point of great interest as up until ISDS and corporate sovereignty was built in as valid clauses in trade agreements, the horizontal axis of disputes between states had to be brought at a governmental level. Philip Morris Asia Limited highlights how a corporation can vertically challenge governments directly and hence was legally able to commence arbitration proceeding against the Australian government in 2011. Philip Morris was able to utilise the intellectual property clause protection in the bilateral agreement between Australia and Hong Kong to argue the ban on its trademarks breached foreign investment provisions of Australia and Hong Kong's 1993 Investment Promotion and Protection Agreement. ${ }^{10}$

What both these cases highlight is, that although the approaches to the decisions were different, there is a real threat to sovereignty and wider public policy by adding intellectual property clauses to international trade agreements.

\section{LIST OF ABBREVIATIONS}

BASCAP - Business Action to Stop Counterfeiting and Piracy

CMLR - Common Market Law Report

EC - European Commission

ECJ - European Court of Justice

EU - European Union

G20 - Group of Twenty

ICC - International Chambers of Commerce

\footnotetext{
${ }^{9}$ Philip Morris Asia Limited v. The Commonwealth of Australia, UNCITRAL, PCA Case No. 2012-12.

10 Investment dispute settlement navigator, INVESTMENT POLICY HuB (Dec. 31, 2019), https://investmentpolicy.unctad.org/investment-dispute-settlement/cases/421/philip-morris-v-australia.
} 
ICSID - International Centre for Settlement of Investment Disputes

IP - International Intellectual Property

ISDS - Investor to State Dispute Settlements

NAFTA - North American Free Trade Agreement

EPO - European Patent Office

TRIPS - Trade Related Intellectual Property Rights

UKSC - United Kingdom Supreme Court

UNCITRAL - United Nations Commission on International Trade Law

WIPO - World Intellectual Property Office

WTO - World Trade Organisation

\section{REFERENCE LIST}

Business Action to Stop Counterfeiting and Piracy (BASCAP), Estimating the Global Economic and Social Impacts of Counterfeiting and Piracy, FRONTIER ECONOMICS (Feb. 2011).

Eli Lilly and Company v. Canada, Case No. UNCT/14/2.

Harvard College's Onco Mouse Application T 19/90 [1990] OJ EPOR 501 (Oct. 3, 1990).

Human Genome Sciences Inc. v. Eli Lilly and Company, [Nov. 2, 2011] UKSC 51.

Investment dispute settlement navigator, InVESTMENT POLICY HuB (Dec. 31, 2019), https://investmentpolicy.unctad.org/investment-dispute-settlement/cases/421/philip-morris-vaustralia.

Merck v. Stephar [July 14, 1981] CMLR 463.

Philip Morris Asia Limited v. The Commonwealth of Australia, UNCITRAL, PCA Case No. 2012-12 (March 8, 2017)

Terrapin v. Terranova [1976] ECR 1039 (June 22, 1976). 